\title{
Magnetostratigraphy of Sediments in the Atlantic Coastal \\ Plain and Pacific Coast of the United States \\ as an Aid for Dating Tectonic Deformation
}

\author{
Joseph C. Liddicoat \\ Neil D. Opdyke \\ Lamont-Doherty Geological Observatory \\ of Columbia University \\ Palisades, New York 10964
}

USGS CONTRACT NO. 14-08-0001-18377

Supported by the EARTHQUAKE HAZARDS REDUCTION PROGRAM

OPEN-FILE NO. $81-232$

U.S. Geological Survey

OPEN FILE REPORT

This report was prepared under contract to the U.S. Geological Survey and has not been reviewed for conformity with USGS editorial standards and stratigraphic nomenclature. Opinions and conclusions expressed herein do not necessarily represent those of the USGS. Any use of trade names is for descriptive purposes only and does not imply endorsement by the USGS. 
FINAL TECHNICAL REPORT

Contract Number: USGS-14-08-0001-18377

Name of Contractor: Lamont-Doherty Geological Observatory of Columbia University

Principal Investigator: Joseph C. Liddicoat

Co-Principal Investigator: Neil D. Opdyke

Government Technical Officer: Gordon W. Greene

Title: Magnetostratigraphy of Sediments in the Atlantic Coastal Plain and Pacific Coast of the United States as an Aid for Dating Tectonic Deformation

Effective Date of Contract: 1 November 1979

Contract Expiration Date: 31 October 1980

Amount of Contract: $\$ \$ 50,000$

Submission Date: 1 November 1980

Sponsored by the U.S. Geological Survey

No. 14-08-0001-18377

The views and conclusions contained in this document are those of the authors and should not be interpreted as necessarily representing the official policies, either expressed or implied, of the U.S. Government. 
Paleomagnetic data from our magnetostratigraphic work in the Atlantic Coastal Plain refines the chronology of sediments along the eastern continental margin between New Jersey and Charleston, South Carolina. Part of the investigation addresses the relationship between four tephra units in the Ventura Basin (California) and several boundaries of the paleomagnetic polarity time scale. Dating the tephra units by the paleomagnetic method is important because the units are diagnostic stratigraphic markers in a tectonically unstable part of western North America and beyond. The results for each area are described separately.

\section{ATLANTIC COASTAL PLAIN}

In our 1979 Final Technical Report, we cited paleomagnetic data that indicate the informal Accomack Formation in the Delmarva Peninsula (Delaware, Maryland, Virginia) has normal paleomagnetic polarity of primary origin (Figs. 1 and 2). We have since documented the polarity by thermal demagnetization (Fig. 3), and presented the data at the 1980 Northeastern Section GSA Meeting (Appendix A). Our findings help in the interpretation of dates acquired by other methods, especially the uranium series dates on corals and amino acid "dates" on Mercenaria, from the sites. The consensus is the Accomack Formation is Brunhes age $(<0.73$ myBP) .

The deposits along the Intracoastal Waterway between the North Carolina-South Carolina State line and Myrtle Beach, South Carolina, are being remapped, and the age assigned to them using amino acid enantiomeric ratios has been reviewed. The investigation is well suited for paleomagnetism because sediments assigned to the Waccamaw and Canepatch formations can be identified by paleomagnetic polarity - the Waccamaw records reversed 


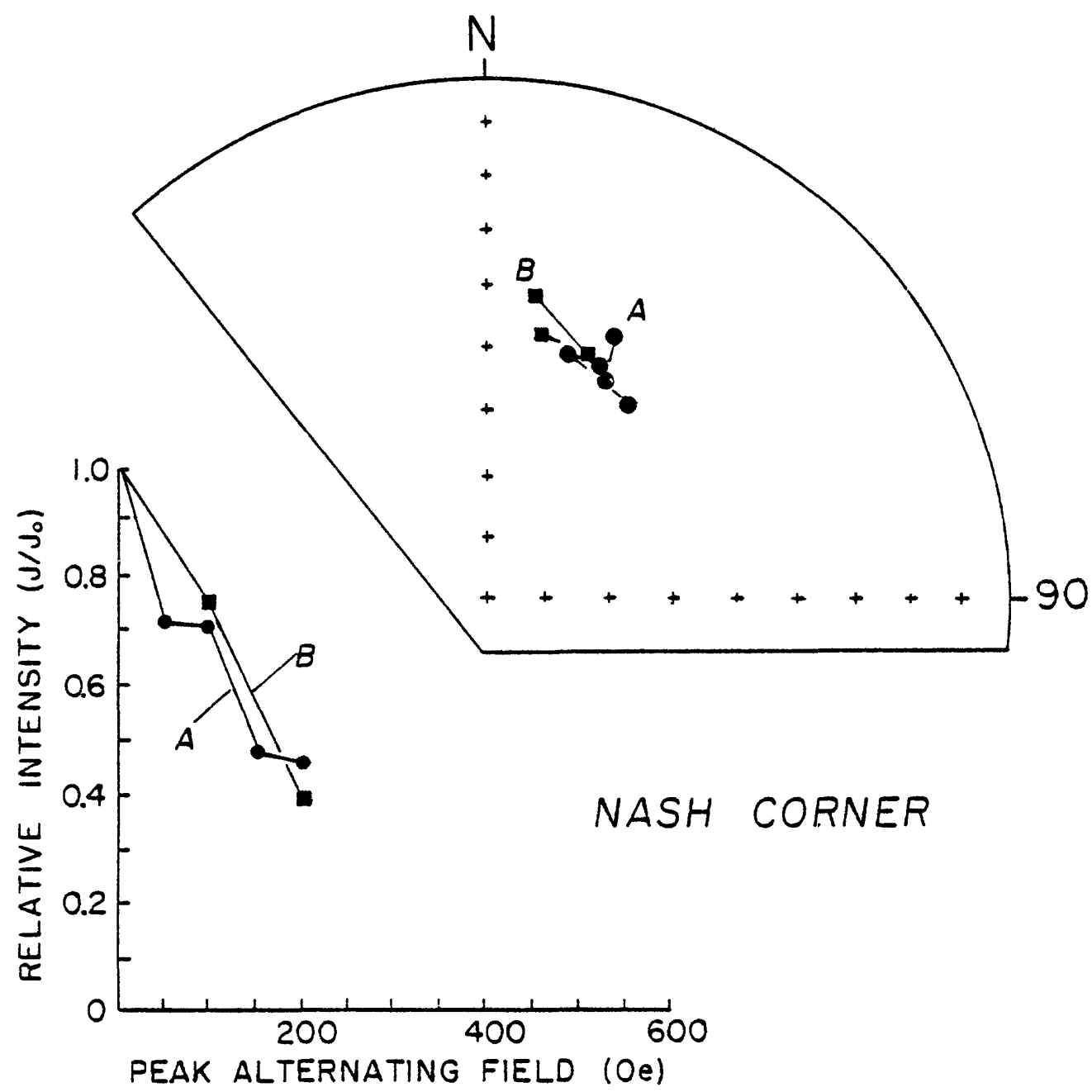

Fig. 1: Equal-area plot of paleomagnetic directions for two adjacent specimens (A, B) from 7.75-m depth in a fully oriented Shelby tube core from Nash Corner (Accomack Fm). Plot of normalized intensity is also shown. The data are for a.f. demagnetization and are plotted on the lower hemisphere. Normal paleomagnetic polarity is recorded. 


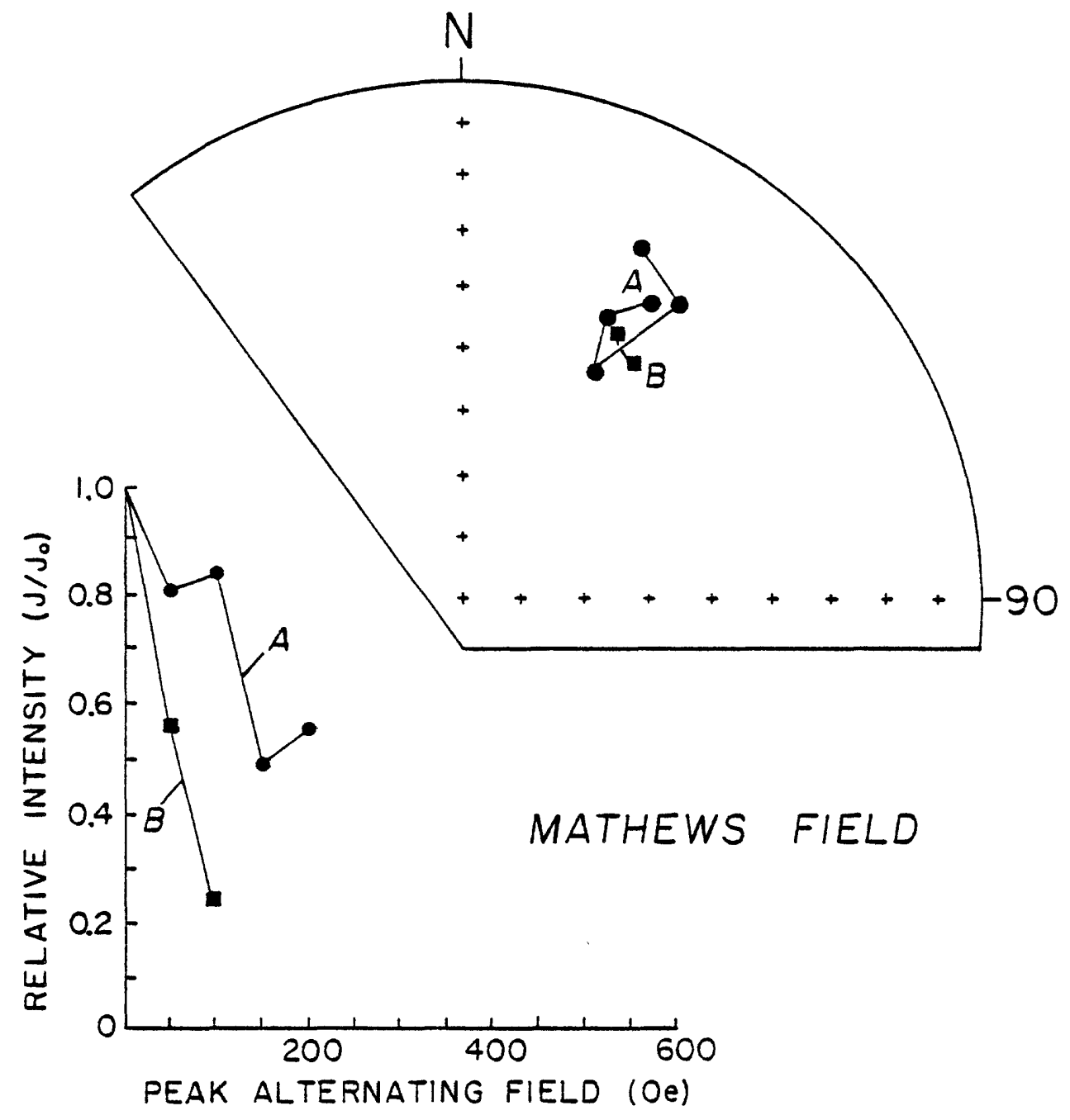

Fig. 2: Equal-area plot of paleomagnetic directions for two adjacent specimens (A, B) from 8.42-m depth in a fully oriented Shelby tube core from Mathew's Field (Accomack Fm). Plot of normalized intensity is also shown. The data are for a.fo demagnetization and are plotted on the lower hemisphere. Normal paleomagnetic polarity is recorded. 

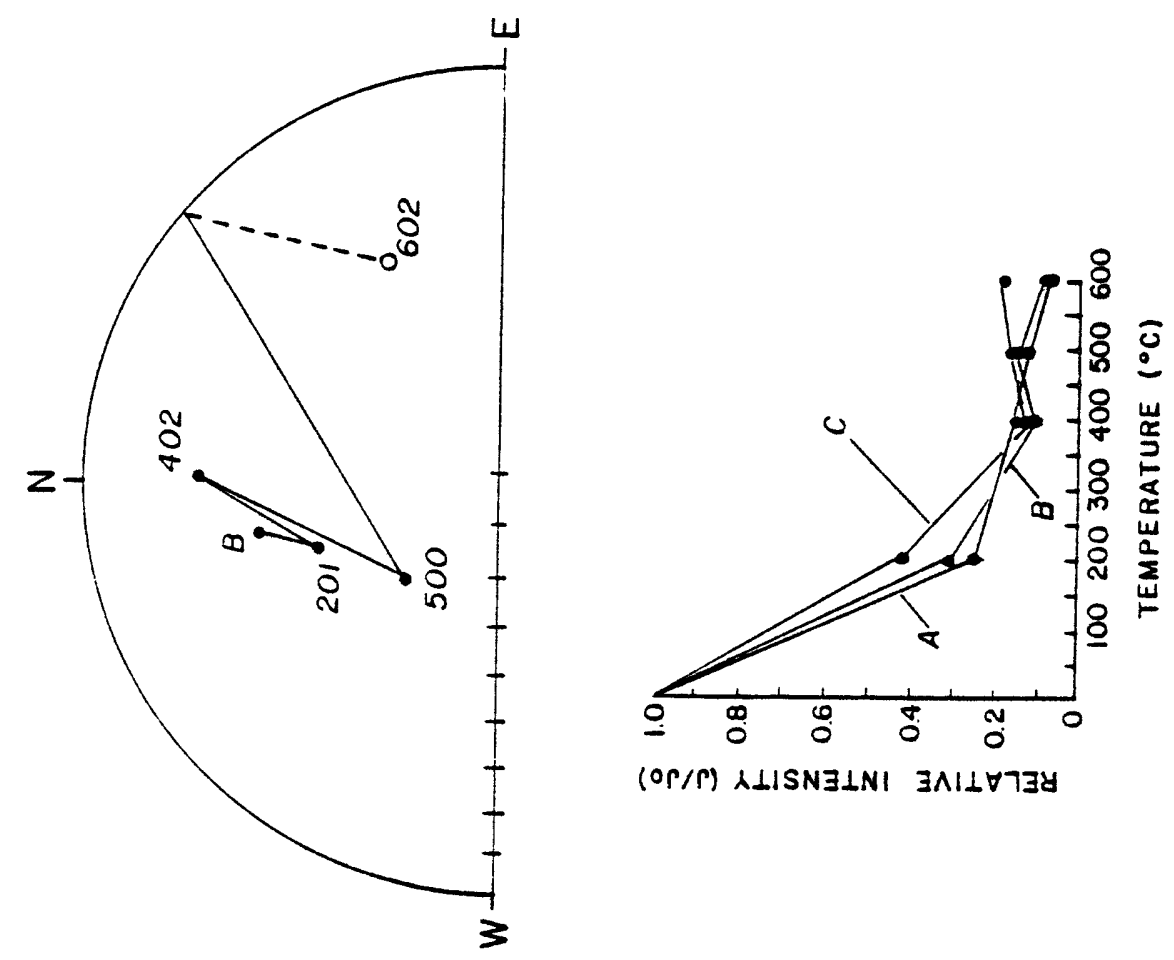



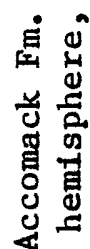

造造

콩

出趈哥

क

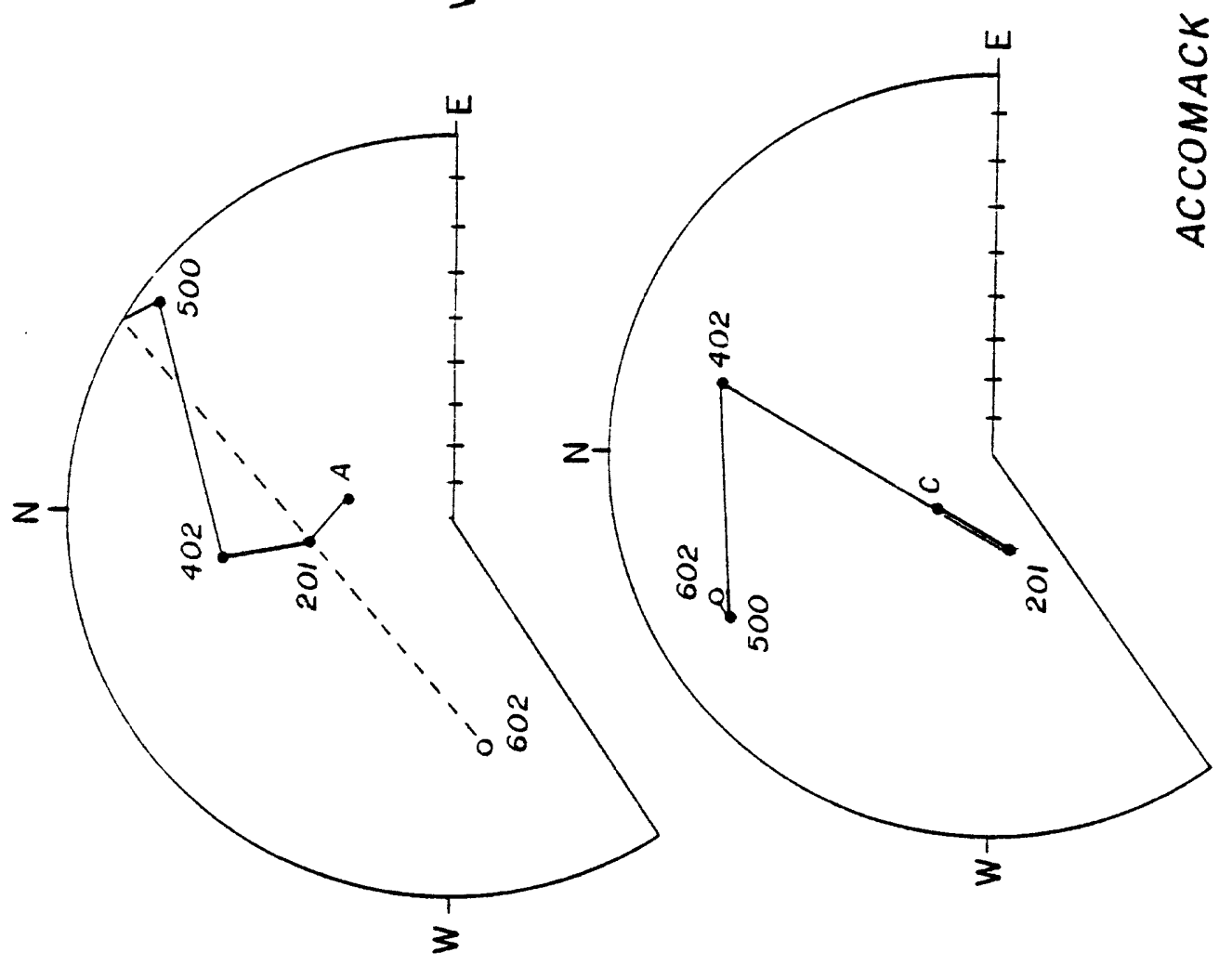

\&

क्ष नु

造

정영

걱

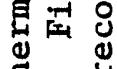

至.

ه

焉

运的

4 品

व ने

苟早

굴

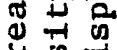

क

空过

票告

矛萧

을

$\ddot{n}=$

. 哥

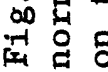


polarity, the Canepatch records normal polarity (Liddicoat, et al., 1979). Paleomagnetic samples collected since last summer indeed record that polarity (Fig. 4), and provide the chronologic information necessary to the evaluation. The river valleys of Virginia and Maryland along the Rappahannock River contain several flights of fluvial and estuarine terrace deposits that range from less than 2 meters to more than 60 meters above mean sea level (Fig. 5). The early to middle Pliocene Yorktown Formation favors reversed polarity following a laboratory shelf test and alternating field (a.f.) demagnetization (Fig. 6). Paleomagnetic samples from the late Pliocene Bacon's Castle Formation record normal polarity that probably reflects a magnetic overprint from oxidation that cannot be removed by a.f. demagnetization; unfortunately, the samples are too fragile to be subjected to thermal demagnetization. We will present the data for Tidewater Virginia at the 1981 Northeastern Section GSA Meeting (Appendix B).

In September, a fully oriented, 30-meter core (Shelby tube) of lacustrine deposits from glacial Lake Passaic (New Jersey) was recovered by the USGS. The core will be used by us and others to determine the age and stratigraphic relationship of Quaternary sediments between the New Jersey Highlands and the Watchung Mountains. The objective as it pertains to the EHRP is to document late Pleistocene and Holocene tectonic deformation in the northern Atlantic Coastal Plain, with attention given to behavior of the Ramapo Fault.

Paleomagnetic samples from 11 horizons (Fig. 7) record normal paleomagnetic polarity following a.f. demagnetization. Agreement of paleomagnetic directions (declination, inclination) between paired samples from depths of 4.6 meters, 16.9 meters, and 23.0 meters is excellent (Fig. 8). At other depths where there is no distortion of the sediment, the paleomagnetic 


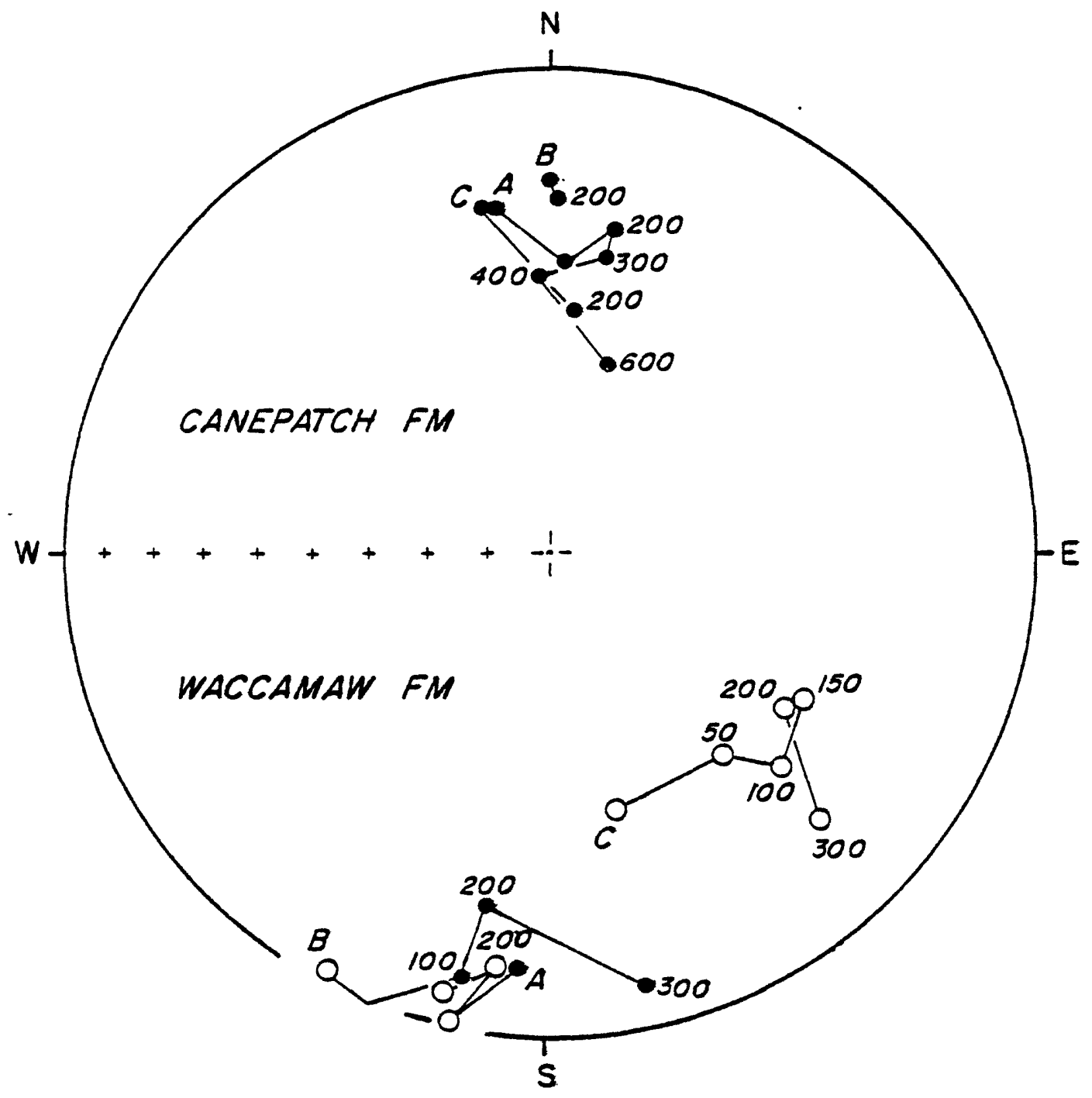

Fig. 4: Equal-area plot of paleomagnetic directions for the Canepatch Formation (Normal polarity) and Waccamaw Formation (Reversed polarity) exposed along the Intracoastal Waterway, South Carolina. The data are for a.f. demagnetization, and numbers adjacent to the symbols indicate the level of demagnetization in oersteds. Solid symbols are plotted on the lower hemisphere, open symbols are plotted on the upper hemisphere. 


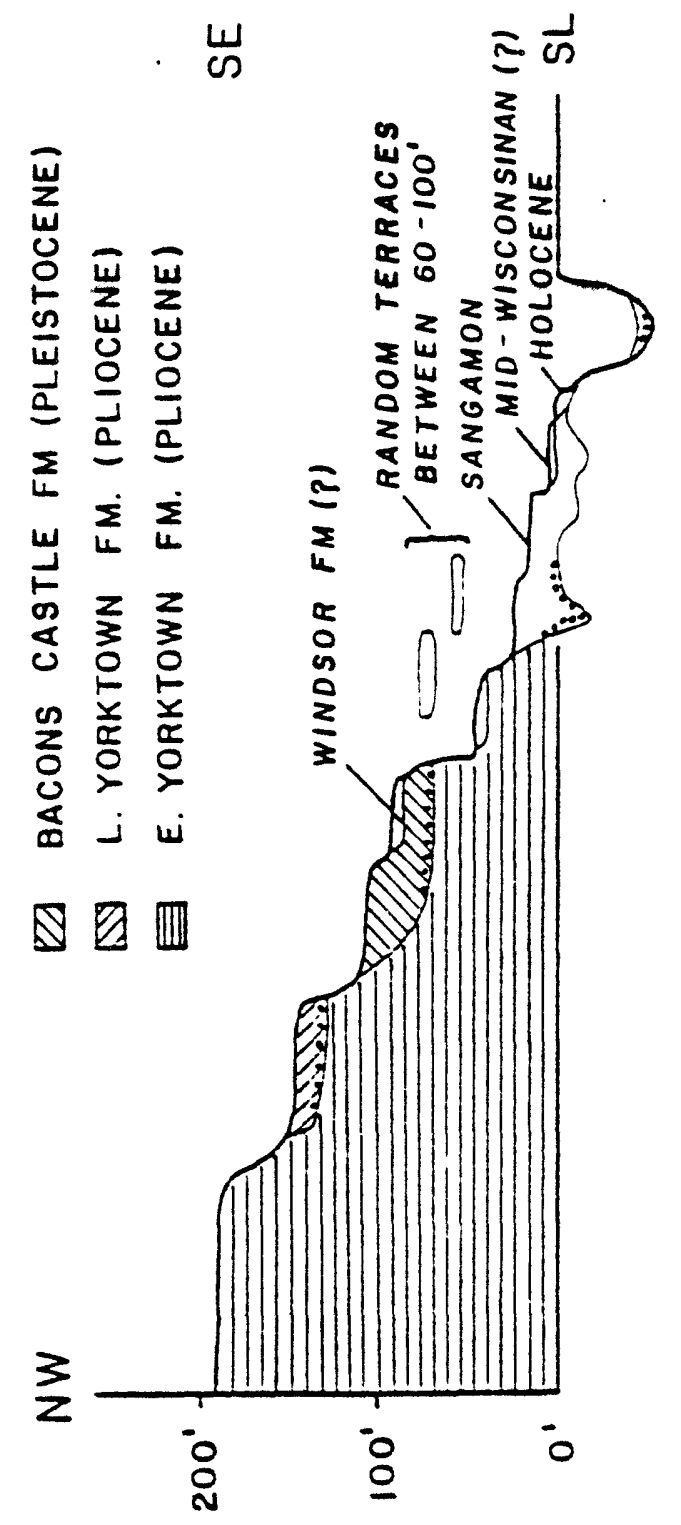

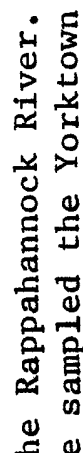

芋

ปै.

$\ddot{g}$

晃

5

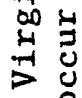

ปัป

窇索

i

㝴

os

प्山 뭉

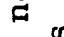

언

동 웅

표

\&

o 0

os t⿹

क 0 स

芹署

$0 \stackrel{1}{0}$

No 0

걱 요

तै

过

过。

त

in $\frac{}{1}$

$\circ \stackrel{0}{0}$

단을 


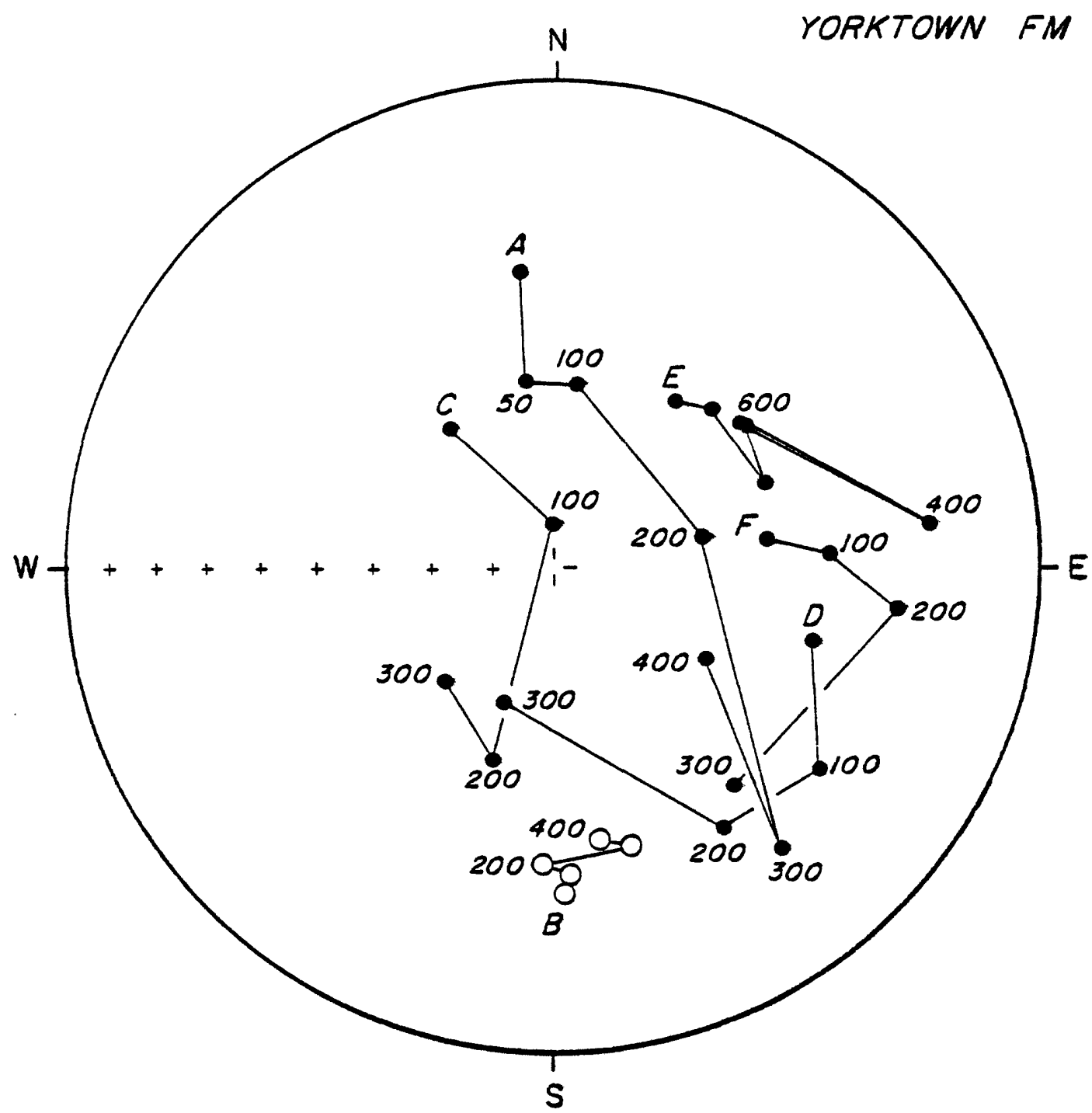

Fig. 6: Equal-area plot of paleomagnetic directions following a.f. demagnetization for the Yorktown Formation. Speciman B is reversely magnetized; the other specimens except $\mathrm{E}$ move to a southerly declination. Solid circles are plotted on the lower hemisphere, open circles are plotted on the upper hemisphere. Numbers adjacent to symbols represent oersteds. 


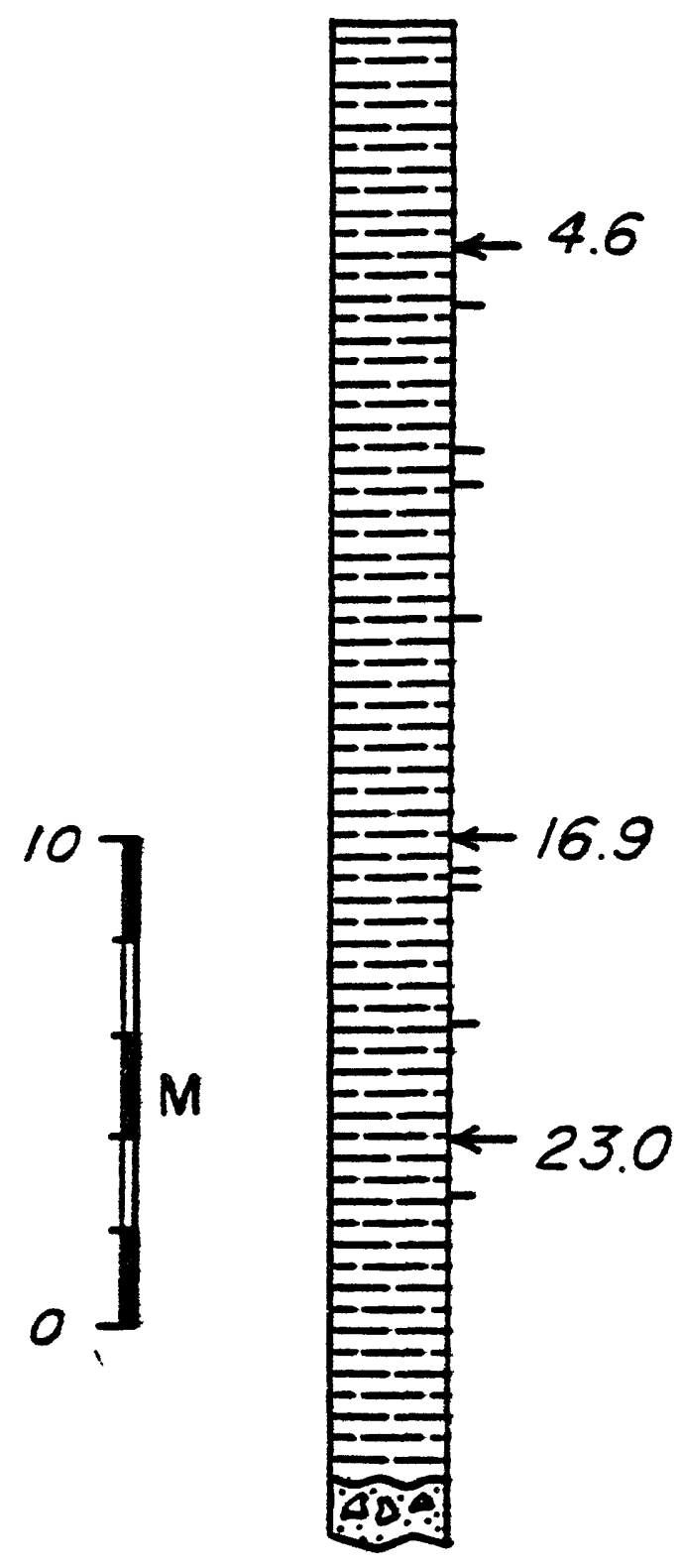

Fig. 7: Generalized columnar section of sediments recovered from glacial Lake Passaic, New Jersey. Lines adjacent to the column indicate horizons sampled. 


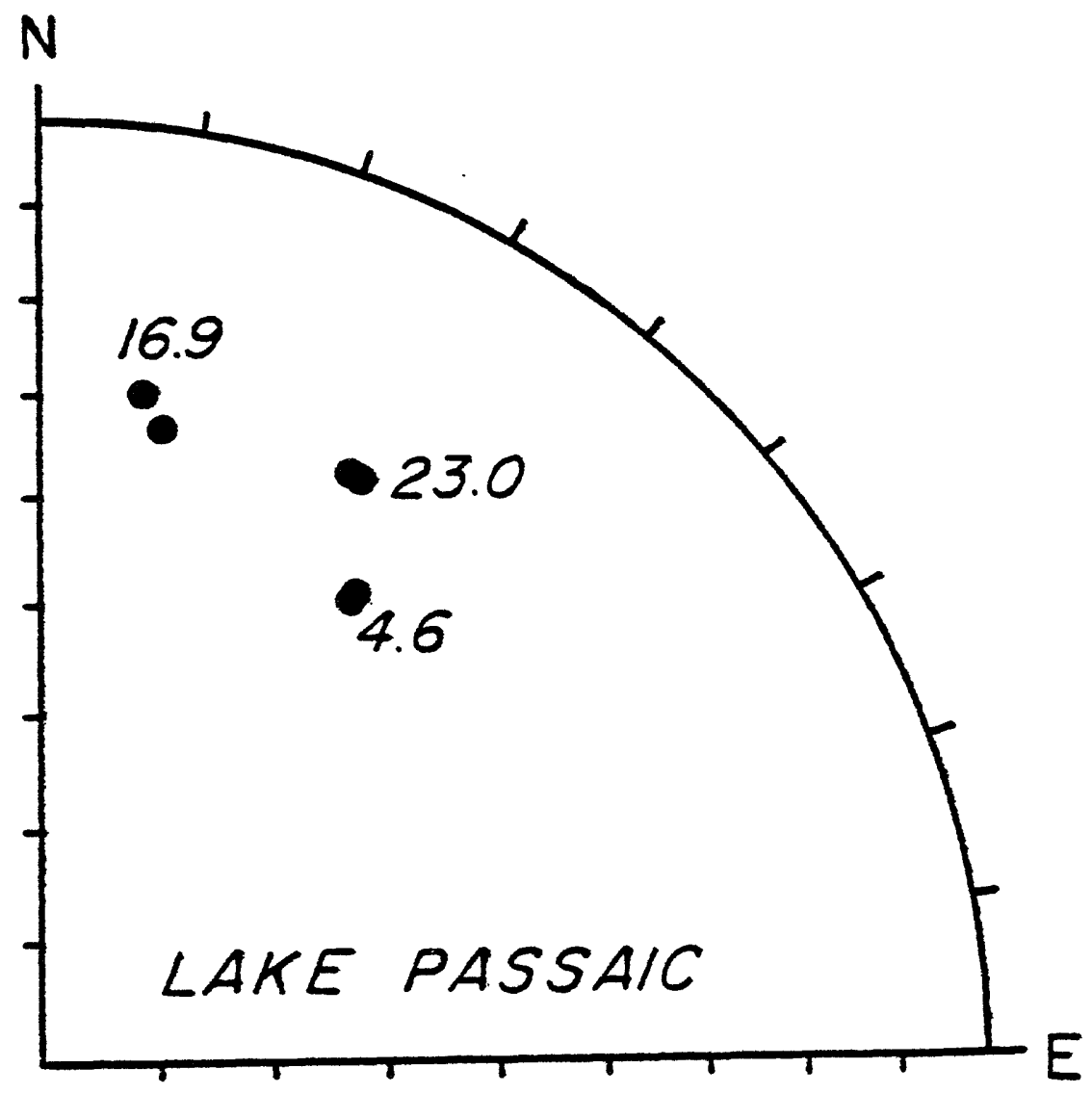

Fig. 8: Equal-area plot of paleomagnetic directions following a.f. demagnetization at 300 oersteds for two specimens from depths of 4.6, 16.9, and 23.0 meters in the Lake Passaic core. Data are plotted on the lower hemisphere and represent normal polarity. 
directions for samples within a horizon match within $\pm 5^{\circ}$. On the basis of those data, we think that if additional, accurately oriented cores are obtained, a high-resolution record of paleosecular variation for the northeastern United States can be compiled that will augment an existing record of declination for northern New York and Lake Ontario (Brennan, et al., 1980). An abstract about our work on the Lake Passaic core was submitted to the 1981 Northeastern Section GSA Meeting (Appendix C).

\section{WESTERN UNITED STATES}

Our paleomagnetic investigation on the West Coast is centered in the Ventura Basin of southern California (Fig. 9). The investigation addresses the relationship between four tephra units exposed on the flanks of the Ventura Avenue Anticline (Fig. 10) and several boundaries of the paleomagnetic polarity time scale. The tephra units and ages assigned to them are the Bishop Ash (0.7 myBP), the "ash of Mono Glass Mountain" (0.9 myBP), the "Ventura Gray Ash"(1.0 myBP), and the Bailey Ash (1.2 myBP) (Fig. 11) (Sarna-Wojcicki, et al., 1980). The polarity boundaries are the Brunhes/ Matuyama (0.73 myBP), the limits of the Jaramillo Normal Subchron (0.9 myBP and 0.97 myBP), and the Cobb Mountain Normal Subchron (1.12 myBP).

The paleomagnetic samples are from fine-grained facies of the Santa Barbara and Pico formations at three localities (Fig. 12). Alternating field and thermal demagnetization coupled with a fold test (the strata dip $45^{\circ}$ about an east-west fold axis) have been used to determine the paleomagnetic polarity. Much of the work has focused on locating the Jaramillo Normal Subchron because it should occur near, possibly between, the "ash of Mono Glass Mountain" and the "Ventura Gray Ash."

In the excavation for an oil well drill platform on Hill 1192 $\left(34^{\circ} 20^{\prime} \mathrm{N}, 119^{\circ} 22^{\prime} \mathrm{W}\right)$ (Fig. 12), the "ash of Mono Glass Mountain," the "Ventura 


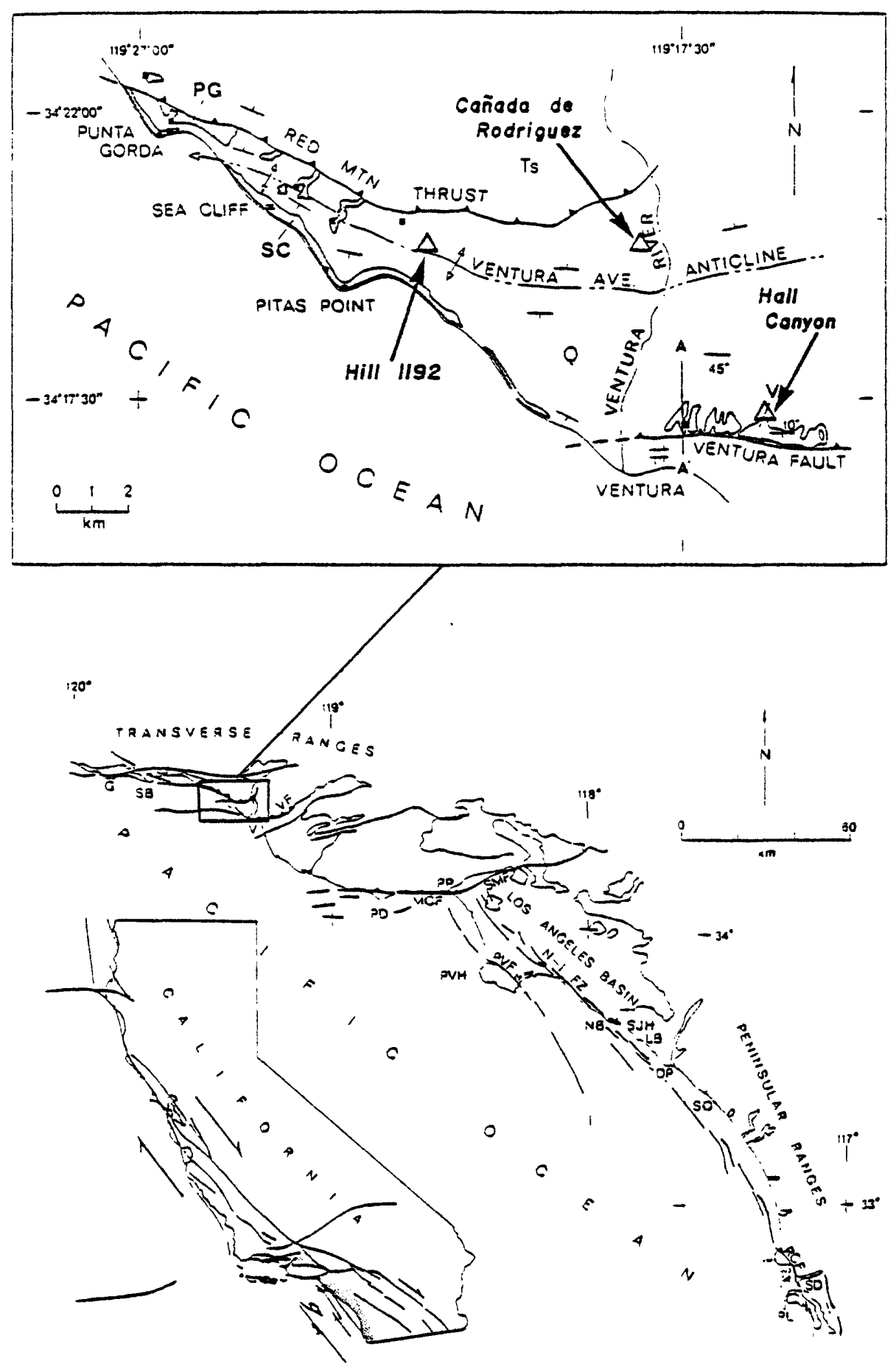

Fig. 9: Location and fault map of southern California coastal region and generalized map (insert) of the Ventura Basin showing major structural features. The three localities where tephra units are exposed are indicated by open triangles. 


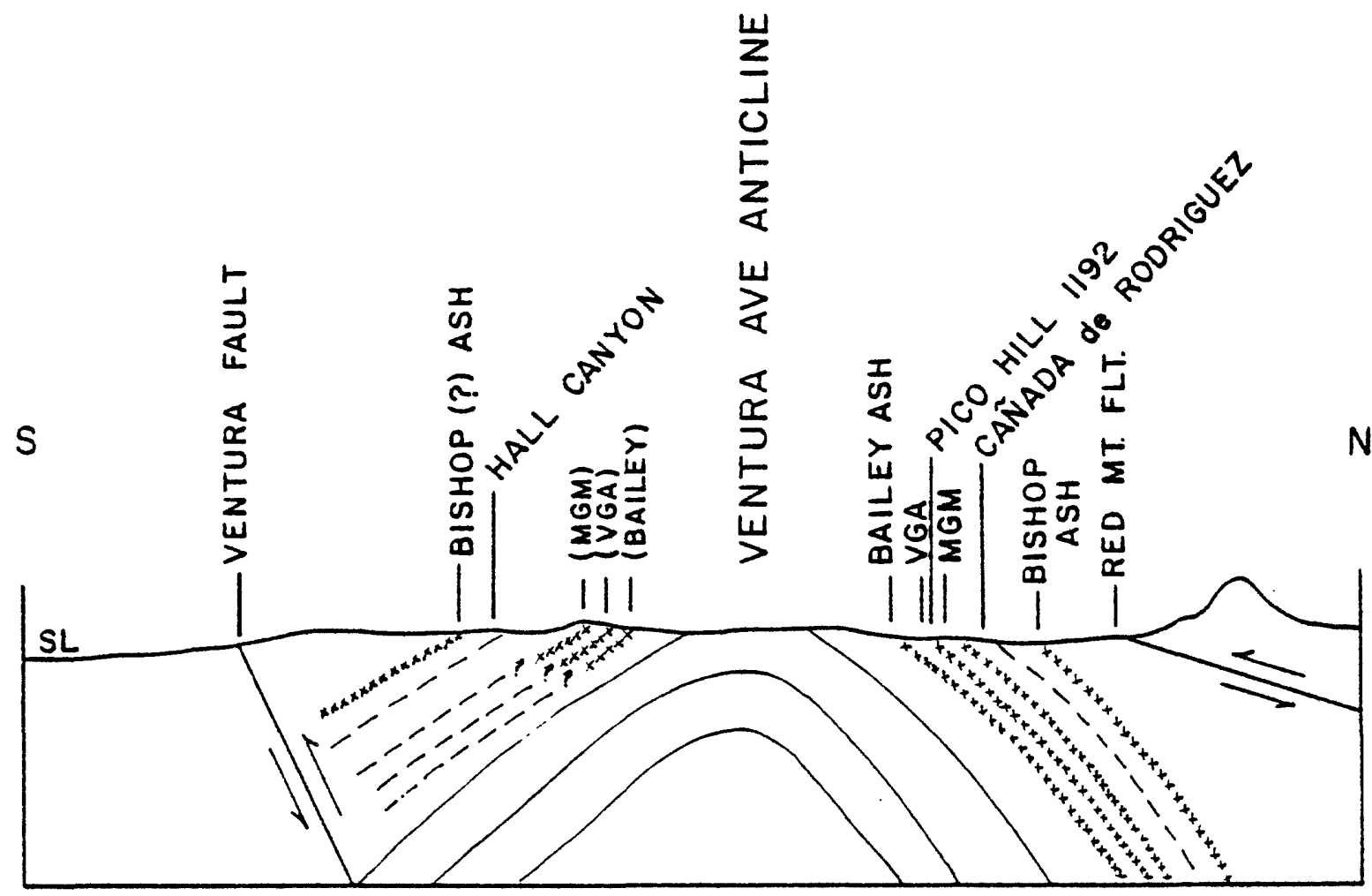

Fig. 10: Cross-section of the Ventura Avenue Anticline showing the location of Hall Canyon, Hill 1192, and Cañada de Rodriguez. 


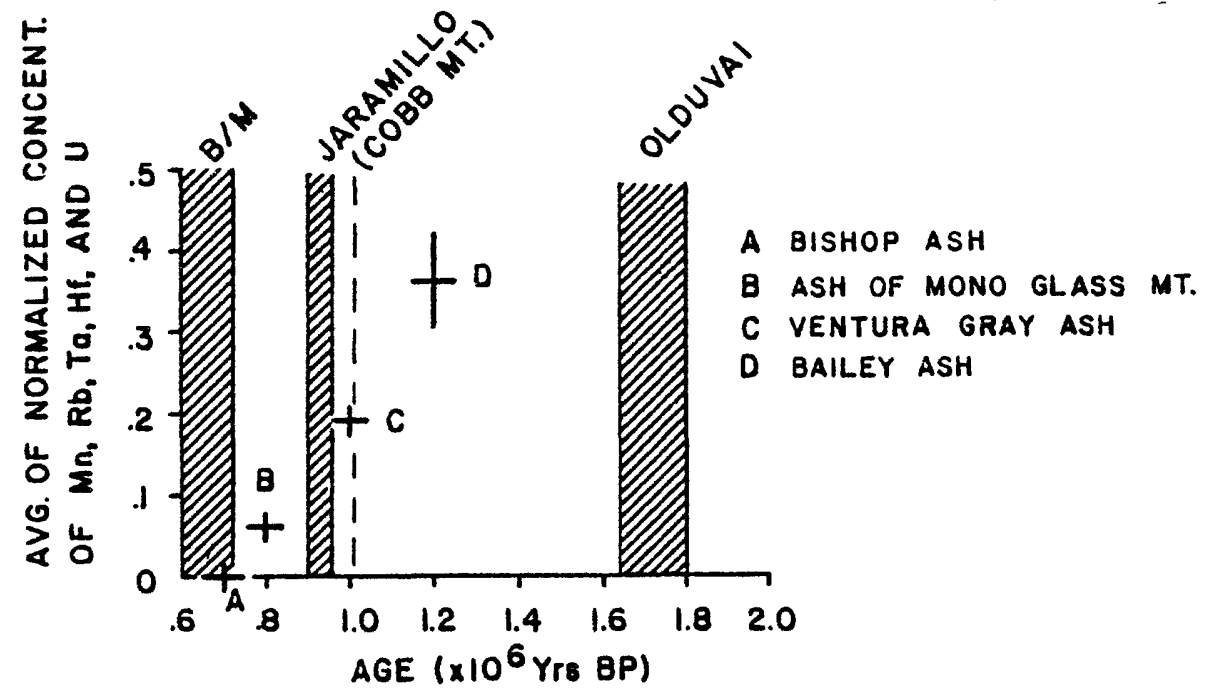

Fig. 11: Average of normalized concentrations of five elements (Mn, $\mathrm{Rb}$, $\mathrm{Ta}$, Hf, and $U$ ) of the four tephra units of interest in the Ventura Basin plotted against their age (modified after Sarna-Wojcicki, et al., 1980). 


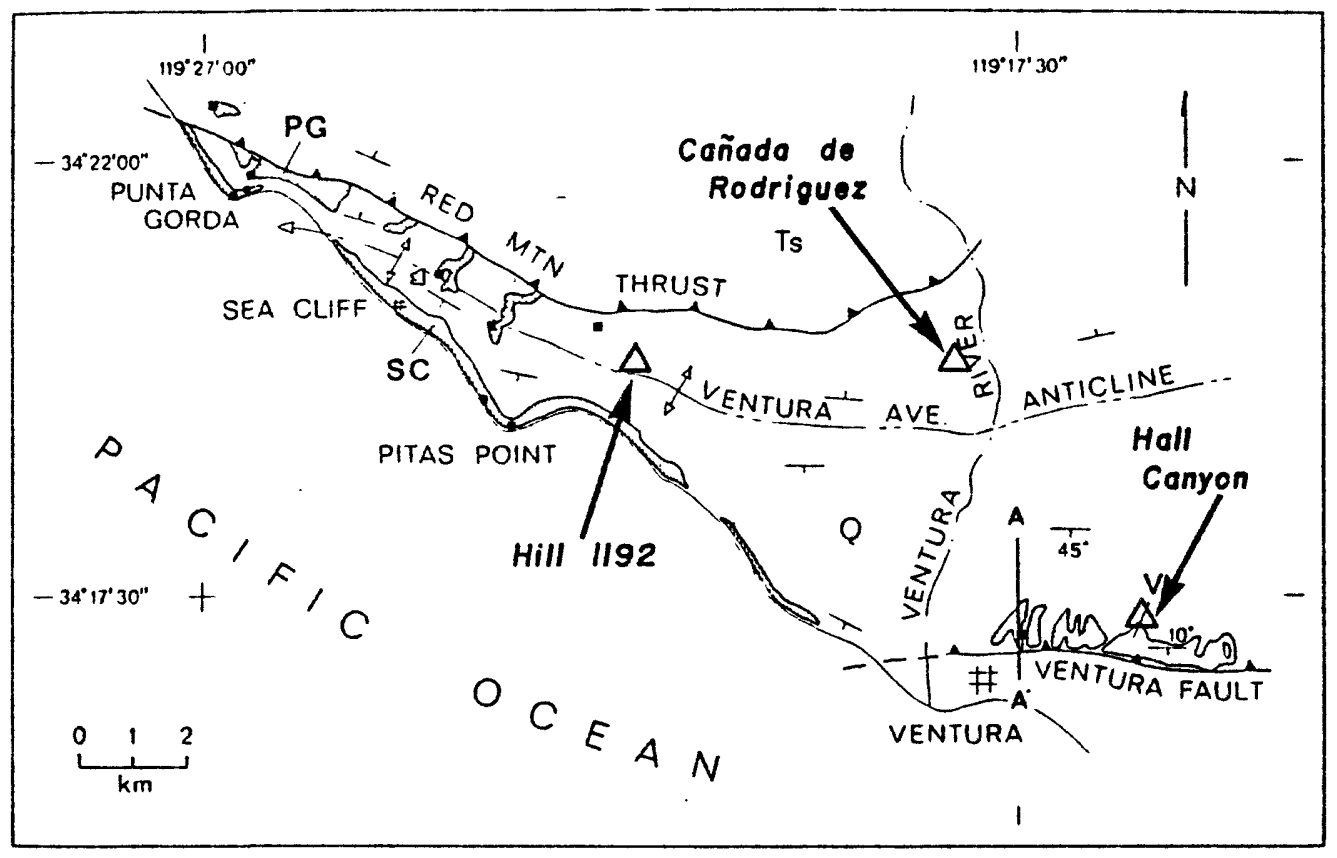

Fig. 12: Location of sites (triangles) where tephra units are exposed on the flanks of the Ventura Avenue Anticline. 
Gray Ash," and the Bailey Ash are exposed in a section of the Pico Formation that is nearly 75 meters thick. We know from paleomagnetic samples of the "ash of Mono Glass Mountain" and the "Ventura Gray Ash" near Bishop, California, that they are reversely magnetized; the Bailey Ash (fission track age: 1.2 0.2 myBP; Izett, et al., 1974) is also reversely magnetized. We can demonstrate by using the fold test that the silt surrounding the "Ventura Gray Ash" and the Bailey Ash record a primary magnetization of reversed polarity (Fig. 13); however, silt adjacent to the "ash of Mono Glass Mountain" was remagnetized by the present normal field. Although we have not located the Jaramillo Normal Subchron in the section (the sampling density is too sparse), we are encouraged that at least portions of the Pico Formation are useful for a magnetostratigraphic investigation. This was further demonstrated in Cañada de Rodriguez $\left(34^{\circ} 20^{\prime} \mathrm{N}\right.$, $\left.119^{\circ} 27^{\prime} \mathrm{W}\right)$, where near the floor of the valley, we sampled a 50-meter section that contains three tephra units (Fig. 14).

The field relationship of the tephra units in Cañada de Rodriguez suggested that the triplet represents the "ash of Mono Glass Mountain," the "Ventura Gray Ash," and the Bailey Ash. However, the paleomagnetic polarity of the intervening siltstone and marl is reversed (Fig. 14), prompting chemical analyses of the tephra. The analyses show that the lowermost tephra unit is the Bailey Ash, but that the two overlying ones are not the "Ventura Gray Ash" and the "ash of Mono Glass Mountain" (A. Sarna-Wojcicki, per. comm., 1980). On the basis of that information, we can direct our search for the "Ventura Gray Ash" and "ash of Mono Glass Mountain," and the Jaramillo Normal Subchron, higher in the section. The investigation has already been fruitful because two previously undetected tephra units were 


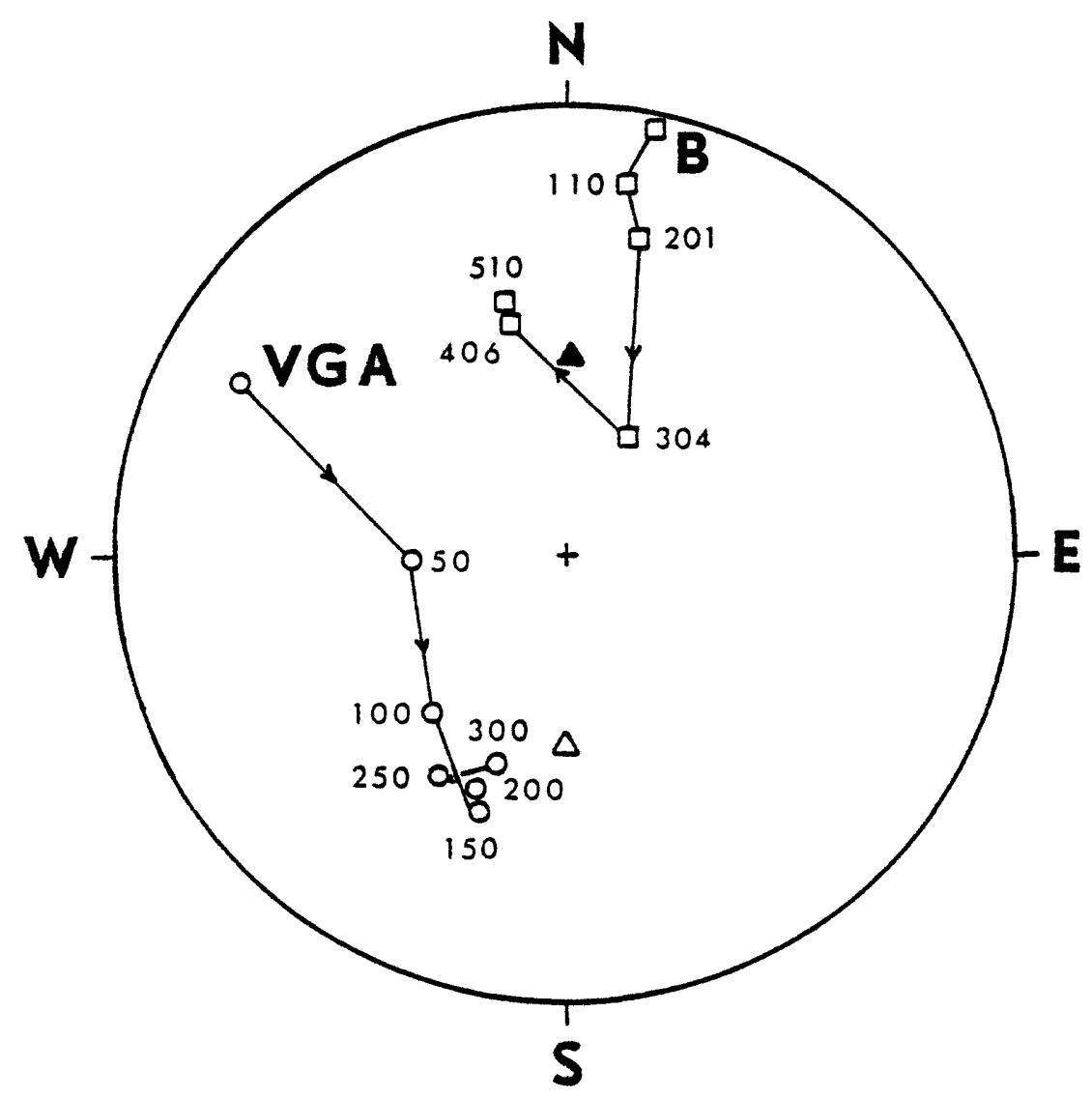

Fig. 13: Equal-area plot of paleomagnetic directions for the "Ventura Gray Ash" and the Bailey Ash at Hill 1192. The "Ventura Gray Ash" was subjected to a.f. demagnetization; the Bailey Ash was subjected to thermal demagnetization. Numbers adjacent to the symbols indicate oersteds or temperature (C). Note that the "Ventura Gray Ash" reaches a reversed direction, but that the secondary magnetization is not completely removed from the Bailey Ash. Data are plotted on the upper hemisphere. 


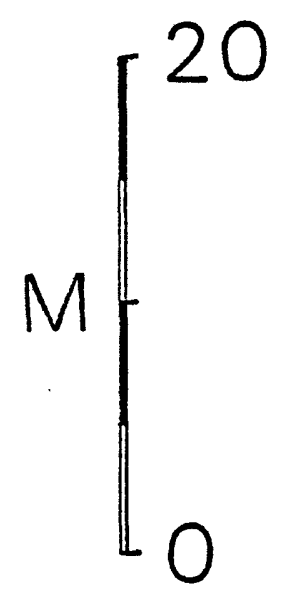

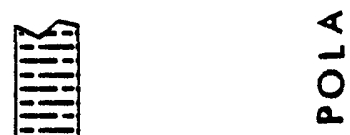

$\frac{2}{a}$

0
0
0
0
0
0

0

0
0
0
0
0
0

0
0
0
0
0
0

0

0
8

0

0

0

$\mathrm{ASH}$

\section{$=$}

Fig. 14: Stratigraphic column of section sampled in Cañada de Rodriguez, Ventura Basin. Circles indicate the position of samples. The samples are reversely magnetized following a.f. demagnetization. 
located that can be fingerprinted chemically and paleomagnetically, which adds to the overall tephrochronologic framework for the region.

In the Santa Barbara Formation in Hall Canyon $\left(34^{\circ} 18^{\prime} \mathrm{N}, 119^{\circ} 15^{\prime} \mathrm{W}\right)$ (Fig. 12), paleomagnetic samples from 70 meters below the Bishop Ash record a primary normal magnetization (Fig. 15). Approximately 100 meters below the site of normal polarity (Fig. 16), the sediments record reversed polarity, as do samples deeper in the section. Thus, we have located the Brunhes/ Matuyama boundary to within \pm 50 meters. Subsequent sampling in Hall Canyon in the approximately five kilometers of exposed section might result in locating the other tephra units and the Jaramillo Normal Subchron.

\section{CONELUSIONS AND RECOMMENDATIONS}

The Brunhes/Matuyama polarity boundary ( 0.73 myBP) that separates the Canepatch Formation $(<0.73$ myBP) from the Waccamaw Formation $(>0.73$. myBP) is a valuable chronologic marker in the southern Atlantic Coastal Plain. Importantly, the boundary provides a cross-check on other methods of dating. That is especially true for evaluating the utility of amino acid enantiomeric ratios for dating Pleistocene fauna.

The reversed polarity of the Yorktown Formation (Matuyama : 2.48-0.73 myBP) augments the identity of the formation where it is being mapped in Tidewater Virginia. Also amenable to paleomagnetic investigation are varved sediments from late Pleistocene and Holocene glacial lakes in the northern Atlantic Coastal Plain. An attempt is being made to use oriented cores of those deposits to document paleosecular variation in the northeastern United States.

Quaternary sediments in the Ventura Basin contain at least four tephra 


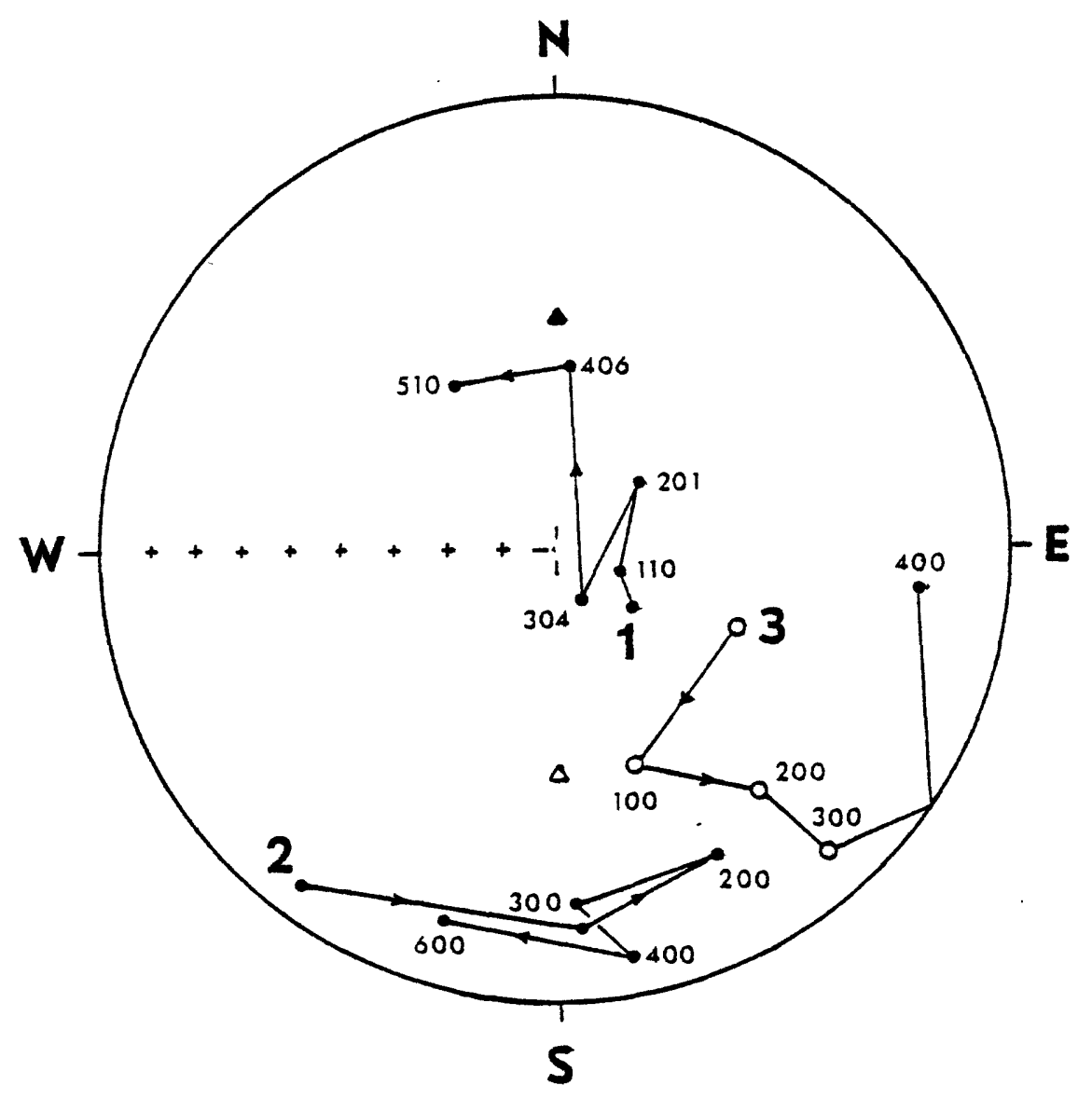

Fig. 15: Equal-area plot of paleomagnetic directions following thermal demagnetization for siltstone (非) approximately 70 meters below the Bishop Ash in Hall Canyon, Ventura Basin. Data for $\# 2$ and 33 are for the sites shown in Fig. 16. Symbols are the same as in Fig. 13 except that solid circles are plotted on the lower hemisphere. 


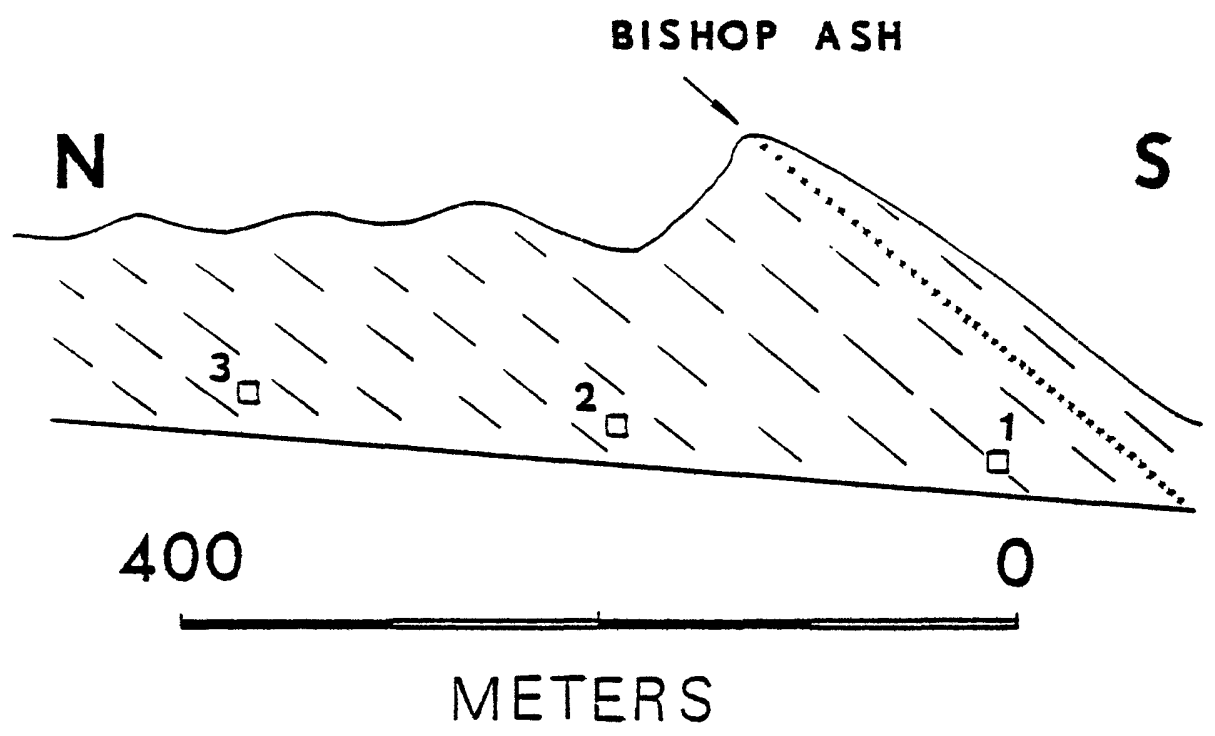

Fig. 16: Cross-section of strata exposed in Hall Canyon, Ventura Basin. Paleomagnetic data for the sites are shown in Fig. 15. 
units that can be valuable stratigraphic markers when accurately dated.

The sediments record a primary magnetization that can be recovered by

laboratory and field experiments. The identity of the Jaramillo Normal

Subchron (0.97-0.9 myBP) will refine the age of two of the tephra units --

the "ash of Mono Glass Mountain" and the "Ventura Gray Ash" -- and will aid

in interpreting the sedimentary and tectonic history of the basin.

\section{REFERENCES}

Brennan, W. J., D. R. Hutchinson, M. J. Hamilton, and R. K. Kilbury, 1980, Holocene and late Pleistocene secular variation in the eastern Great Lakes region: Abstracts with Programs, 1980 Ann. Meetings, Geol. Soc. Am., v. 12, no. 7, p. 391 .

Izett, G. A., C. W. Naeser, and J.' D. Obradovich, 1974, Fission-track age of zircons from an ash bed in the Pico Formation (P1iocene and Pleistocene) near Ventura, California: Abstracts with Programs, 1974 Ann. Meetings, Geol. Soc. Am., v. 6, no. 7, p. 197.

Liddicoat, J. C., B. W. Blackwelder, T. M. Cronin, and L. W. Ward, 1979, Magnetostratigraphy of Upper Tertiary and Quaternary Sediments in the Central and Southeastern Atlantic Coastal Plain: Abstracts with Programs, 1979 Southeastern Section Meeting, Geol. Soc. Am., v. 11, no. 4, p. 187.

Sarna-Wojcicki, A. M., H. W. Bowman, C. F. Meyer, P. C. Russe11, F. Asaro, H. Michael, J. J. Rowe, and P. A. Baedicker, 1980, Chemical analysis, correlations, and ages of Late Cenozoic tephra units of East-Central and Southern California: U.S. Geol. Survey Open-File Report, 80-231, 53 p. 
APPENDIX A

Abstract Presented at the 1980 Northeastern Section GSA Meeting Philadelphia, Pennsylvania, 15 March 1980

PALEOMAGNETIC INVESTIGATION OF PLEISTOCENE SEDIMENTS IN THE DELMARVA PENINSULA, CENTRAL ATLANTIC COASTAL PLAIN

LIDDICOAT, Joseph C., Lamont-Doherty Geological Observatory, Columbia

University, Palisades, NY 10964; MIXON, Robert B., U.S. Geological

Survey, National Center, MS 925, Reston, VA 22092

Unconsolidated sand, silt, and clay of marginal marine origin, herein informally called the Accomack deposits, record a major transgression of the sea in the southern Delmarva area in Pleistocene time. The paleomagnetic studies were initiated to help evaluate widely varying absolute ages obtained for the Accomack deposits by different laboratory dating techniques.

Outcrop samples and fully orlented, brass Shelby-tube cores (7-cm diameter) from several localities in the central upland west of Chincoteague, Virginia, have magnetization of normal paleomagnetic polarity. Two coring sites, Nash (T's) Corner and Mathew's Field, are of particular interest because the section includes shell beds studied by radiocarbon, uranium-serles, and amino-acid-racemization dating methods. At the coring sites, samples of dark-gray clayey silt at 7.7.5-m (Nash Corner) and 8.42-m (Mathew's Field) depths have nearly identical paleomagnetic directions following demagnetization in a 200-0e peak alternating field. The lithology, the virtual lack of change in paleomagnetic direction during demagnetization, and the demagnetization spectra (median destructive field is $150 \mathrm{Oe}$ ) show no evidence for a stable secondary magnetization. Samples from three nearby outcrops were demagnetized the same way and gave similar results. Therefore, on the basis of the paleomagnetic data and stratigraphic relationships to adjacent rock units of late Pleistocene age, we consider the Accomack deposits to be of Brunhes age $(<0.73 \mathrm{m.y.})$. From the outcrop sections, we also collected samples for thermal demagnetization, soon to be completed. 
Abstract Submitted for the 1981 Northeastern Section GSA Meeting Bangor, Maine, 9-11 April 1981

\author{
PALEOMAGNETIC INVESTIGATIONS OF LATE NEOGENE DEPOSITS IN NORTHERN \\ TIDEWATER, VIRGINIA \\ LIDDICOAT, Joseph C., Lamont-Doherty Geological Observatory, \\ Columbia University, Palisades, New York 10964; NEWELL, Wayne, \\ U.S. Geological Survey, National Center, Mall Stop 925, Reston, \\ Virginia 22092
}

The tidewater river valleys of Virginia and southern Maryland contain numerous flights of fluvial to estuarine terrace deposits. Elevations of the terraces range from less than 2 meters to more than 60 meters. Regional mapping of the terrace deposits in the Rappahannock River Valley reveals the evolution of the modern estuary from early Pliocene to present. Samples from these deposits have been used to extend the late Neogene magnetostratigraphy in the Central Atlantic Coastal Plain. The results are in agreement with the paleomagnetic polarity expected for the deposits of known age.

Paleomagnetic samples from early to middle Pllocene (Yorktown Formation) record reversed polarity following a laboratory shelf test, alternating-field (a.f.) demagnetization, and measurement in a cryogenic magnetometer. Paleomagnetic samples from the late Pliocene (Bacon's Castle Formation) record normal polarity, probably reflecting a secondary overprint from oxidation that cannot be removed by a.f. demagnetization. Paleomagnetic samples from a high level fluvial terrace (late Pliocene or early Pleistocene) favor reversed polarity after a.f. and thermal demagnetization, suggesting a pre-Brunhes ( 0.73 yrBP) age.

Stable, secondary magnetization from oxidation is a ubiquitous problem encountered in all shallow, near surface outcrops. We anticipate collecting fully oriented (Shelby tube) cores of unoxidized sediment from the Pliocene and early Pleistocene to overcome that problem. 
Abstract Submitted for the 1981 Northeastern Section GSA Meeting Bangor, Maine, 9-11 April 1981

\author{
GLACIAL LAKE PASSAIC: PRELIMINARY CORING, PALEOMAGNETIC AND \\ STRATIGRAPHIC ANALYSIS \\ REIMER, G.E., ASHLEY, G.M., Department of Geological Sciences, \\ Rutgers University, New Brunswick, N.J. 08903; LIDDICOAT, J.C., \\ Lamont-Doherty Geological Observatory, Columbia University, \\ Palisades, N.Y. 10964; PAVICH, M.J., STONE, B.D., U.S. Geolog- \\ ical Survey, National Center, Ma11 Stop 928, Reston, VA 22092 \\ Glacial Lake Passaic in northern New Jersey was dammed during the late \\ Wisconsinan glacial maximum and covered $540 \mathrm{~km}^{2}$ at its greatest extent. \\ The objectives of this multidisciplinary study are to determine ages \\ and stratigraphic relationships of Quaternary sediments deposited in \\ the lake betweem the New Jersey Highlands and the Watchung Mountains. \\ Continuous cores as much as $50 \mathrm{~m}$ long are being analyzed for texture, \\ mineralogy, palynology, and paleomagnetism. \\ Data from more than 200 wells and boreholes show that the basin \\ contains as much as $60 \mathrm{~m}$ of unconsolidated sediment. Facies identified \\ are lacustrine clay and silt, fluvial and lacustrine sand, and multiple \\ tills interbedded with probable lacustrine sediments. A core from $8 \mathrm{~km}$ \\ south of the Wisconsinan terminal moraine, sampled $30 \mathrm{~m}$ of lacustrine \\ silt and clay including $18.9 \mathrm{~m}$ of uninterupted, rhythmically layered \\ clay and silty beds. When interpreted as varves, these rhythmites \\ indicate a minimum of 600 years of glacial damming of the lake during \\ the Wisconsinan glacial maximum. No pre-Wisconsinan sediments were \\ penetrated in this core. Another core from Fairfield about $14 \mathrm{~km}$ \\ north of the terminal moraine sampled $5.8 \mathrm{~m}$ of coarse oxidized fluvial \\ sand overlying $3.4 \mathrm{~m}$ of irregularly laminated lacustrine silt and clay \\ and $4 \mathrm{~m}$ of probable till. \\ Oriented paleomagnetic samples from 11 horizons record normal \\ paleomagnetic polarity. Agreement of paleomagnetic directions \\ (declination (D), inclination (I)) between paired samples from depths \\ of $4.6 \mathrm{~m}, 16.9 \mathrm{~m}$, and $23.0 \mathrm{~m}$ is excellent $\left(\Delta D<2^{\circ}, \Delta I<2^{\circ}\right)$. At other \\ depths where there is no apparent distortion of the sediment, the \\ paleomagnetic directions for samples within a horizon deviated by \\ about $\pm 5^{\circ}$.
}

